\title{
ASPEK KEAGAMAAN DALAM KEHIDUPAN SOSIAL MASYARAKAT BUGIS DI DAERAH BONE SULAWESI SELATAN
}

\author{
H. Abubakar Surur
}

Pengungkapan nilai-nilai ketakwaan yang hidup dalam sistem sosial masyarakat Bugis, khususnya yang terwujud dalam bentuk praktek atau tindakan, tidak terlepas dari budaya bangsa Indonesia yang menempatkan Ketuhanan Yang Maha Esa sebagai masalah yang sentral. Kesadaran akan aspek keagarnaan yang tinggi menunjukkan bahwa masyarakat Bugis, yang menipakan bagian dari bangsa Indonesia, adalah masyarakat religius.

Penelitian ini mengungkapkan aspek keagarnaan dalam kehidupan sosial masyarakat Bugis, sebagaimana yang terungkap dalam bentuk praktek, tingkah-laku dan tindakan sehari-hari, sekaligus juga mencerminkan kehidupan sosial mereka.

Agama dalam konteks ini adlah seperangkat pengetahuan, kepercayaan, perbuatan.tindakan-tindakan, danpengalamanpengalaman keagarnaan berkenaan dengan $y^{\wedge} n g$ gaib. Pengertian didasarkan kepada definisi yang dikemukakan oleh Dr. Parsudi Suparlan, Yaitu : "Suatu sistem keyakinan yang dianut dan tindakan-tindakan yang diwujudkan oleh suatu kelompok masyarakat dalam mengatasi dan memberi respins terhadap apa yang dirasakan dan diyakini, sebagai gaib yang suci (Roberston : 1988, V).
Untuk mengungkapkan aspek keagarnaan dalam kehidupan sosial masyarakat di desa sampel penelitian, digunakan disiplin antropologi dengan pendekatan kualitatif dan dilihat secara holistik, yaitu melihat suatu tindakan atau pristiwa, bukan dari gejala saja, tetapi dicari juga maksud yang terkandung dalam setiap gejala itu. Disamping itu digunakan juga pendekatan kuantitatif.

Cara yang dilakukan dalam pengumpulan data, adalah : a. pengamatan terlibat terhadap kegiatan upacara sosial yang mengandung nilai ritual ; b. Wawancara mendalam dengan pemuka-pemuka agama, tokoh-tokoh masyarakat, pejabat pemerintah, tentang tradisi dan upacara-upacara setempat;

Penelitian dilakukan di Desa Allamungeng PatuE, salahsatu desa dari 10 desa yang adadi Kecamatan Ajangale Kabupaten Bone, dengan luas wilayah $17 \mathrm{~km} 2$, dengan jumlah penduduk 2.894 orang, terdiri dari laki-laki 1.311 orang dan perempuan 1.583 orang, dengan 592 KK. Penduduk tersebar pada $10 \mathrm{RW}$ dan terbagi menjadi $21 \mathrm{Rt}$. Penduduk seluruhnya menganut agama Islam.

Desa Allamungeng PatuE dipimpin oleh seorang kepala desa (Andi Alam Nur) 
dibantu oleh seorang sckretaris desa (Abd.Azis) dan tiga orang kepala urusan, masing-masing urusan pemerintahan (A.Rosman), kepala urusan pembangunan (A. Anas) dan kepala urusan umum (Mallangenni). Disamping itu, terdapat 5 dusun yang dikepalai seorang kepala dusun, masing-masing kadus Bunne (A.Oddang), Kadus Sumpanglawo (Maggu), Kadus Kawerang (A.Sulolipu), Kadus Amessangeng (A.Salam) dan Kadus Tokasa (A.M.Said).

Lembaga-lembaga yang ada di Desa Allamungeng PatuE adalah LKMD di Kctuai oleh Nur Ali, LMD, PKK dan Aparat Syara' tcrdiri dari Imam Desa dan Imam Dusun, Khatib (Katte), Bilal (Bilala) dan Khadim (Doja).

Allamungeng PatuE yang menjadi nama dari desa lokasi penelitian ini, berasal dari tiga rangkaian suku kata, yaitu : "Allamungeng" artinyatempatmcnanam, "patu" artinya batu, dan "e" merupakan akhiran yang berarti tempat. Jadi Allamungeng PatuE berarti tempatmenanam batu. Adapun scbab dinamakan demikian, karena dalam tahun 1582, Raja Bone kctujuh yang bergelar "La Tenriruwa BongkangE MatinroE ri Gucinna" bersama Arung Matowa Wajo kesebelas yang bernama "La Mungkace Toudammang MatinroE ri Batana" dan Datu Soppcng ketigabelas bernama "La Mappaleppe PatolaE", membuat suatu "Pcrsckutuan Tiga Kerajaan" di kampung Bunne (sekarang Dusun Bunne). Maksud utamadari pcrsekutuantcrsebut adalah untuk mcnentang supcrmasi Gowa atas ketiga kerajaan terscbut. Pcrsckutuan ini dikcnal dengan "MatlcllumpoccoE" (Tiga kerajaan menyatu dalam persekutuan). Dalam perjanjian persekutuan tersebut, antara lain diucapkan oleh ketiga raja, yaitu :

"Malilu sipakainge, rebba sipatokkong, sipadapi riperi rinyameng, tellu tessibaiccukeng, tessiancinnaiyang ulaweng tasa, patola malampe, warangparang maega, naiyya teya ripakainge iya riduwai".

Artinya : Yang lupa diperingati, yang tumbang ditegakkan, salingmenyampaikan kesusahan dankegembiraan, ketiganya sama kedudukan, tidak menghendaki penguasaan emas dan harta benda, siapa yang tidak ingin diperingati, dialah yang diserang.

"Rekkuwa engka maceko, nakkatenni marunrung, nalla maili, temmita deceng".

Artinya: Siapa yang khianat, pegangannya runtuh, tempatnya berpijak longsor, tidak dapat kebaikan selama-lamanya. Untuk mcmperkuatpernyataanbersamaketigaraja tersebut dalam persekutuan ini, masingmasing mengangkat sumpah, kemudian masing-masing mcnanam batu. Ketiga batu yang ditanam ketiga raja (Bone, Wajo, Soppcng), kini masih dapat disaksikan di desa ini. Bahkan ketiga batu tersebut, menjadi pemujaan dan ramai didatangi orang, icrutama bila selesai pancn atau satu hajat tclah dilaksanakan maka mereka dalang di tempat ini melepas hajat (mappalcppc hajja). Mcrcka yang datang, membawa makanan dan memotong hewan (kambing atau ayam) dan disertai oleh dukun.

\section{Kehidupan Sosial Masyarakat.}

Dalam masyarakat Desa Allamungeng PatuE mengcnal 3 macam pclapisan sosial, masing-masing : 1) Golongan bangsawan 
(Arung) merupakan lapisan paling atas; 2) Golonganmenengah/orang baik-baik (todcceng); dan 3) Golongan budak (ata) adalah lapisan terendah. Golongan ata ini hampir tidak ditemukan lagi di dalam masyarakat, kalaupun masih ada mereka tidak akan mengakui lagi dirinya sebagai ata (budak), apalagi kalau sudah berpendidikan.

Strata sosial seseorang, nampak dalam pergaulan sehari-hari. Bila berbicara dengan golongan bangsawan digunakan sapaan "puang" dan golongan menengah menggunakan sapaan "daeng" bagi yang lebih tua dan bagi yang lcbih muda dari usia kita disapa dengan "ndi". Bila ada upacara atau pcrjamuan, baik adat atau kcagamaan ataupun pribadi, tamu-tamu dari golongan bangsawan tcmpat duduknya dibentangkan tikar dan duduk di scbelah selatan dan golongan biasa di scbelah utara. Selanjutnya semakin kc utara menunjukkan semakin rendahnya status sosialnya seseorang.

Bentuk penghidangan makanan/ minuman pada acara adat, juga nampak perbedaan menurut golongan. Menghidangkan makanan bagi golongan bangsawan, memakai dulang besar, kemudian pinggan yang akan digunakan, dipakai baki kecil sebagai pelapis, begitu juga untuk minum dipakai baki dan gclasnya 2 buah memakai penutup, walau yang dibutuhkan 1 gelas saja. Bagi golongan menengah, dilakukan sepcrti biasa saja, cukup dengan membentang pelapis dari kain dan hidangan diatur diatas kain tcrscbut. Namun, dewasa ini mulai bcrkurang pclayanan demikian, disamping alatnya yang sudah berkurang, situasinya juga sudah berubah.

Struktur kepemimpinan di Desa Allamungeng PatuE, secara formal, bcrada di tangan kepala desa, yang membawahi lima kepala dusun. Kepala dusun lebih dekat kepada masyarakat, karena ia lebih banyak berkomunikasi dengan anggota masyarakat. Selain pemimpin formal, dalam masyarakat terdapat juga pemimpin non formal, mereka adalah tokoh-tokoh masyarakat dan pemukapemuka agama, yang turut memegang pcranan dalam masyarakat menurut bidangnya masing-masing, misalnya petani memilih orang yang dituangkan (tomatowa) yang sangat berpcran dalam menentukan waktu tanam, turun sawah dan panen.

Antara pemimpin formal dan non formal scnantiasa terjalin hubungan dan kerjasama yang baik. Kepala Desa banyak berkonsultasi dengan tokoh masyarakat dan pemuka agama dalam mclayani dan memenuhi kcbuluhan masyarakat.

Sistem kekerabatan bagi masyarakat Allamungcng PatuE adalah" wari asseajing" (kcrabat), yang masih termasuk bagian dari "pangadereng". Konsep "assiajingeng" (kekerabatan) di Desa Allamungeng PatuE tidak tcrlepas dari kekerabatan di Daerah Bone umumnya, dimulai sejak masa "To Manurung ri Matajang" yang menjadi Raja Bone Pertama, yang kawin dengan "To Manurung ri Toro". Kekerabatan ini 2 macam: "Rcppc" (sanak) yaitu kekerabatan karena adanya hubungan sedarah. "Sompunglolo" ialah kcrabat karena adanya pcr talian pcrkawinan diantara keluarga.

Sistem pcrkawinan yang bcrlaku bagi masyarakat, bcrkisar dalam lingkungan sendiri, dalam istilah Bugis disebut "siparcwekenna", yaitu memilih jodoh dari sepupu dan yang paling disukai adalah scpupu dua kali (sappokaduwa), ini dimaksudkan agar pcrtalian darah yang 
sudah cenderung melangkah jauh, ditautkan kembali. Dan yang berperanan dalam mcnjodohkan antara mereka adalah nenck atau kakek. Namun, dcwasa ini pemuda cenderung mcmilih jodoh sendiri dan sudah jarang yang akan dijodohkan dengan sepupu atau keluarganya sendiri.

\section{II}

Masyarakat Desa Allamungeng PatuE sclaku penganut agama Islam, percaya kepada Tuhan Yang Maha Esa yang mereka scbutkan "Puang Allah Ta'ala". Scbagai pemeluk Islam, Allah adalah di atas scgalagalanya. Konsep takwa scbagai aspek keagamaan mereka, adalah hidup dengan kctaatan, tunduk dan mengabdi kepada Puang Allah Ta'ala, dengan mclaksanakan scgala perintahNya dan menjauhi scmua laranganNya. Konsep takwa yang momiliki dimensi vertikal dan horizontal tcrscbut, senantiasa dipelihara melalui pranatapranata lokal sebagaimana tercermin pada corak kebudayaan dan tradisi mereka.

Aspek keagamaan dalam praktck kctakwaan disini adalah mencakup hubungan manusia dengan Tuhan (Allah) dan hubungan dengan dunia gaib (malaikat, jin dan makhluk halus). Untuk menjalin hubungan dengan Allah, mereka mclakukan bcrbagai ibadah berupa pelaksanaan rukun Islam (shalat, zakat, puasa dan haji bagi yang telah mampu). Ibadah shalat mereka laksanakan dengan berjamaah. Di desa ini terdapat 5 buah masjid dan 1 buah langgar. Shalat jamaah yang paling ramai adalah shalat magrib, sedang shalat jamaah lainnya bervariasi, shalat jamaah Isya ramai juga kemudian shalat jamaah subuh. Scdangkan shalat jamaah dhuhur dan ashar tidak seramai dengan 3 macam shalat wajib lainnya.

Dalam berbagai hal yang dilakukan, senantiasa dimulai dengan membaca Surah Al-Fatihah yang ditujukan kepada nabi yang mereka scbutkan "Petta Nabie" dengan harapan untuk mendapatkan bcrkah. Pada upacara adat atau upacara keagamaan, selalu diadakan bacaan barzanji (mabbarasanji), walaupun mereka tidak mengerti makna yang dikandung kitab barzanji tersebut, tctapi mereka yakin, bahwa membacanya akan mcnumbuhkan kembali kecintaan mereka kepada Nabi Muhammad SAW yang senantiasa mereka harapkan syafaatnya.

Upacara keagamaan yang tidak pernah dilcwalkan, adalah : peringatan maulid dan isra'/mi'raj, dengan acara-acara tertentu disamping bacaan barzanji. Hari asyura dirakan dengan pembacaan do'a dan pembuatan makanan berupa kolak dengan bahan tujuh macam dari buah-buahan, mereka namakan "bella pitunrupa". Hampir tiap kcluarga mcmbuat makanan seperti itu, dan saling mengantarkan ke tetangga. Hari asyura ini dipcringati tiap tahun pada tarikh 10 Muharram. Nisfu Sya'ban diperingati tiap-tiap tarikh 15 sya'ban di tiap masjid dengan acara membaca surah Yasin dan do'anya 3 kali berturut-lurut, dengan niat 3 macam pula, sebclum bacaan yasin dimulai. Niat pertama memohon kepada Allah untuk dipanjangkan umur, kedua agar mendapat kemantapan iman, dan ketiga agar Allah memberikan rezeki yang halal. Acara ini dilakukan antara waktu magrib dan Isya dan setelah acara selesai, dilakukan makan bersama yang mereka bawa sendiri dari rumah masing-masing. 
Menanam padi bagi masyarakat Bugis dilakukan oleh kaum pria dengan gotong royong, sedangkan wanita hanya menyediakan makanan dan menghidangkannya. Menanam padi dilakukan pada waktu pagi hari dan sawah yang akan ditanami harus selesai sebelum matahari tergelincir. Kalau matahari sudah tergelincir, penanaman padi dihentikan. Kalau masih ada sawah yang belum ditanami sampai saat matahari tergelincir, maka penanamannya ditunda sampai besoknya. Maksudnya agar padi dapat tumbuh dengan baik, sama dengan naiknya mata hari. Ada semacam mitos, kalau padi ditanam setelah matahari tergelincir, padi mudah diserang hama atau binatang lainnya.

\section{Upacara Panen}

Bila waktu panen tiba, Sesepuh pctani lebih dahulu ke sawah memeriksa padi dan memilih sawah yang akan mulai dipanen. Setelah sawah terpilih, sesepuh mcmberitahu pemilik sawah dan mengundang tetangga untuk panen; Panen dimulai oleh sesepuh dengan membaca "basmalah" disamping mantra lainnya. Menunai padi dilakukan oleh kaum wanita, sedangkan lakilaki hanya mengumpulkan padi yang sudah dipanen untuk diikat (Bugis : mabbesse).

Selesai panen para petani menyatakan syukur dengan acara berzanji dipimpin oleh imam dusun dan hidangan makanannya adalah beras dari padi yang baru dipanen. Disamping acara barzanji, pesta panen diadakan juga oleh masyarakat, berupahiburan tcrdiri dari: mappadendang (menggunakan lesung dan antan dari kayu yang ditabuh bcramai-ramai oleh gadis-gadis dan menimbulkan bunyi yang berirama); Massempe (adu kekuatan betis); dilakukan oleh pemuda; Mattojang (ayunan, yang diayun adalah gadis-gadis dan yang mengayun pemuda); Mappasajang (main layanglayang) dilakukan oleh semua lapisan baik anak-anak, remaja, pemuda, maupun orangtua.

Padi, hasil panen yang sudah diikat, dikeringkan beberapa hari, kemudian dinaikkan ke rumah dan disimpan di loteng rumah (bugis : rakkeang) yang dibikin khusus untuk menyimpan padi, letaknya di atas sebab menurut kepercayaan mereka bahwa padi itu harus tinggal di atas karena ia adalah "sangiangseri" berasal dari manusia juga.

\section{B. UPACARA PERKAWINAN}

Sebelum acara pesta pcrkawinan, terlebih dahulu diadakan pendekatan antara kedua belahpihak mclalui tahap-tahap yang memerlukan banyak waktu, yaitu dimulai dengan :

a. Mappese'pese' (pendekatan) sebagai pendahuluan meminang.

b. Madduta/Massuro (meminang) yaitu dengan mengutus beberapa anggota keluarga pihak laki-laki ke rumah pihak pcrempuan dengan mengikut-sertakan imam atau penghulu untuk menyaksikan. Bila sudah tercapai kesepakatan, imam mengakhiri dengan membaca do'a.

c. Mappettu ada (kata sepakat) dimaksudkan untuk menentukan segala sesuatu yang berkaitan dengan perkawinan. Yang dibicarakan adalah : uang belanja, maskawin, hari nikah, pakaian pengantin, dan pesta perkawinan. 
Kesepakatan yang dihasilkan, diikat dengan acara "mappasiarekeng", pihak pria menyerahkan sebentuk cincin kepada pihak wanita. Acara ini juga diakhiri dengan doa.

d. Pada malam hari yang disepakati untuk akad nikah dan pesta, dilakukan acara "Tudangpenni" dengan rangkaian acara : mappacci dengan menggunakan daun pacar yang sudah ditumbuk halus dan diletakkan di telapak tangan calon pengantindan dilakukan beberapa orang yang dianggap sesepuh. Setelah mappaci selesai, diadakan bacaan barazanji dilanjutkan dengan khatam an Al-Qur' an, yang dilakukan oleh guru yang pernah mengajarnya mengaji. Acara tudangpenni dilaksanakan sampai larut malam.

e. Pada hari yang telah disepakati, calon pengantin laki-laki diantar ke rumah calon pengantin wanita untuk dilakukan akad nikah, yang dilaksanakan menurut ajaran Islam, dan pestanya dilakukan dengan acara adat. Sesudah akad nikah dan pembacaan ta'lik-talak, pengantin laki-laki diantar ke kamar tempat pengantin wanita untuk "mappasikarawan" (pengantin laki-laki menyentuh kulit atau memcgang pengantin wanita sehingga wudhu'nya batal). Setelah Sikarawa, kedua pengantin duduk bcrsanding, untuk mendapatkan ucapan sclamat dari hadirin.

f. Sorehari dilakukan lagi acara "marola" yaitu pengantin wanita bersama pengantin laki-laki diantar ke rumah pengantin laki-laki, untuk diperkenalkan dengan scluruh kcluarga, dimulai orangtua, baru keluarga lainnya. Dalam acara marola, pengantin wanita mendapat oleh-oleh dari seluruh keluarga dekat pengantin laki-laki.

Scbagai penutup dari acara perkawinan, pada malam harinya diadakan bacaan barzanji dan doa bersama sebagai pernyataan syukur, dipimpin oleh imam desa.

g. Tiga atau empat hari scusai perkawinan, dilakukan lagi ziarah kubur oleh kedua suami-isteri disertai keluarga dekat, dipandu oleh imam dusun atau imam desa setempat. Ada semacam kepercayaan, menyampaikan kepada leluhur mercka atas perkawinan yang telah dilaksanakan itu dengan baik. Kedua suami-isteri membaca doa di atas kubur yang di ziarahi dituntun oleh imam dan kemudian keduanya membcri sedekah kepada imam tersebut.

\section{KELAHIRAN}

Upacara-upacara tradisional yang menyangkut kelahiran, di mulai dengan acara :

a. Makkatenni sanro (menentukan dukun bayi yang kelak akan mengurusnya) setelah ada tanda-tanda kehamilan pada diri seorang wanita, pada bulan pcrtama atau kedua. Pada hari yang dianggap baik, orangtua istcri mcmbawa beberapa lembardaun sirih dan buah pinang disertai uang selcmbar (nilainya tidak tcrikat) kepada dukun yang akan ditunjuk mcrawat ibu dan bayi kelak.

b. Mappanre tomangideng (mcnyuguhkan makanan bagi istri yang hamil). Acara ini sepenuhnya dilaksanakan oleh dukun. 
Calon ibu duduk dihadapan dukun lalu dukun bayi membakar lilin kemudian diputarkan sekeliling kepala ibu bayi tiga kali, kemudian calon ibu bayi memadamkan lilin.

Sesudah itu, dukun menyuapi calon ibu makanan yang sudah disiapkan sebelumnya. Sesuah itu, dukun melakukan pemeriksaan pertama pada perut sang calon ibu. pada saat menyentuk perut calon ibu, dukun membaca mantra sambil memercikkan air ke perut calon ibu. Kemudian pada bulan ketujuh, diadakan lagi acara "maccera babuwa", yaitu selamatan dengan menyembelih ayam dan dimakan bersama, yang didahului dengan membaca doa. Maksudnya agar ibu dapat melahirkan bayinya dengan selamat.

c. Kelahiran seorang bayi adalah saat yang dinantikan oleh keluarga kedua belah pihak, baik pihak suami maupun pihak istri. Bila calon ibu sudah merasakan adanya tanda kelahiran, dukun dipanggil dan mulai sang dukun sibuk dengan mantra dan peralatannya. Setclah bayi lahir, dukun yang mengurus dan merawatnya. Rangkaiannya adalah : memotong tali pusar (maddette lolo), kemudian bayi dibersihkan. Sesudah itu, ayah sang bayi dipanggil untuk azan pada telinga kanan dan qamat pada telinga kiri sang bayi. Hal ini dilakukan karena dianjurkan oleh Nabi, dan dimaksudkan agar yang pertama-tama didengar oleh si bayi, adalah kalimat yang mengandung nama-nama Allah. Pada hari ke enam kelahiran bayi, diadakan lagi acara "maruwae lawi", yaitu acara memandikan ibu dan bayi dengan air biasa.
Upacara ini biasanya dirangkaikan dengan aqiqah. Untuk acara ini, diadakan bacaan barzanji. Dan pada waktu berdiri membaca salawat, sang bayi diangkat keluar untuk digunting rambutnya oleh beberapa orangtua dimulai imam yang memimpin pembacaan barzanji. Sebelum pembacaan barzanji, sang ibu diantar oleh dukun untuk mandi di sumur atau di sungai, dan beberapa keluarga membawa sesajen berupa "sokko patanrupa" (nasi ketan diberi warna empat macam, yaitu hitam, kuning, merah dan putih) dan seekor ayam yang sudah dimasak, dialirkan di sungai tempat ibu bayi dimandikan.

Rangkaian "maruwaelawi" (turunmandi air biasa) pada hari ketujuh kelahirannya, sang bayi juga "dipenre tojang" (mulai diayun). Ayunan dibuat dari kain putih atau sarung yang digantung diantara tiang rumah dan dibawah ayunan diletakkan benda-benda tajam (keris atau pisau).

Pada upacara kelahiran, dukun masih tetap berperan demi keselamatan bayi tersebut.

\section{KEMATIAN}

Pelaksanaan pengurusan mayat bila ada kematian dilakukan sepenuhnya menurut ajaran Islam, namun unsur-unsur adat yang merupakan tradisi lidak ditinggalkan, sehingga pengurusan jenazah berbaur antara tuntunan ajaran Islam dan tradisi, sebagai berikut:

1. Ripamadang(mcnunggumenjelang ajal),

- dilakukan oleh keluarga seseorang yang sudah sakarat. Imam dipanggil membacakan surah yasin sedang lainnya 
menuntun membacakan kalimat tauhid (La Ilaaha Illallah). Hal ini dilakukan sampai yang bersangkutan menghembuskan nafas terakhir.

2. Riuju'(dilayat).

Mayat dibaringkan membujur ke arah kiblat, kepalanya disebelah timur dan tangannya dilipat seperti orang dalam shalat, disebut "madduangrakang". Sekujur badan ditutup dengan kain panjang. Tiap pelayat yang datang, membuka penutup dan melihat wajah jenazah dan mendoakannya.

3. Ricemme (dimandikan). Memandikan jenazah ada dua macam, yaitu : a. Ricemme Tutuwo, dilakukan 1 atau 2 jam sesudah seseorang meninggal. Memandikannya sama dengan memandikan seseorang yang masih hidup. 2 . Ricemme parellu, yaitu memandikan jenazah menurut ajaran Islam. Pada saat dimandikan, mayat dipangku minimal 3 orang dari keluarga dekatnya, dipandu oleh pegawai syara'.

4. Riwalung (dikafani), sepenuhnya dilakukan menurut ajaran Islam. Bila jenazah adalah laki-laki, yang mengafani adalah laki-laki dan wanita dikafani oleh wanita.

5. Risempajangi (dishalati).

Shalat jenazah dilakukan dua kali, yaitu :

a. Sempajang, tungke, yaitu mayat dishalati hanya satu orang, yaitu ulama yang diminta kesediaannya oleh keluarganya.

b. SempajangTomate, dilakukan berjamah dipimpin pegawai syara' sesudah sempajang tungke selesai.

6. Riule (diusung ke kubur).
Membawa mayat ke kubur masih diusung oleh pengantar. Pada saatjenazah dimasukkan ke dalam usungan, tidak langsung diangkat ke bahu yang akan mengusung, tetapi diangkat lcbih dahulu ke atas permukaan tanah baru diturunkan lagi, berturut-turut scbanyak tiga kali, baru langsung diangkat ke bahu untuk setcrusnya diantar ke kubur. Mengusung mayat, para pengantar bergantian.

7. Rilemme (dimakamkan).

Setelah kubur selesai digali, seorang pegawai syara' turun lebih dahulu ke kubur untuk menerima mayat untuk dibaringkan di liang lahad, yang disebut "pappasuru", dibantu 2 orang keluarga si mayit. Sesudah dikuburkan, disiram dengan air biasa dan ditaburi daun pandan. Sebagai tanda, ditanamkan batu nisan, 1 buah bagi laki-laki dan 2 buah bagi wanita. Kemudiandibacakan talqin oleh imam.

Tiga hari sesudah jenazah dikuburkan, keluarga dekatnya datang menziarahi pusaranya, dan memanggil imam untuk membacakan surah yasin dan mendoakannya.

\section{E. UPACARA SELAMATAN}

Untuk keselamatan jenazah, dilakukan upacara-upacara berikut:

a. Mattasebbe (pembacaan tasbih) dilakukan sesudah shalat ashar selama 3 hari berturut-turut. Pada hari ketiga dilakukan juga tadarusan Al-Qur'an dan tahlilan.

b. Pada hari ketujuh, dilakukan selamatan "esso pitunna" (hari ketujuh meninggalnya seseorang), dengan menyembelih kambing atau sapi bagi 
yang mampu. Ada juga sesajen yang turut dihidangkan tetapi tidak boleh dimakan, karena diperuntukkan bagi arwah almarhum. Dalam acara hari ketujuh, diadakan tahlilan dan khataman Al-Qur'an.

c. Mattampung (pemasangan batu nisan). Pada hari keempatpuluh setelah mcninggal, keluarga mengadakan upacara dengan mengundang scluruh keluarga dan tetangga serta sahabat. Pada acara ini dilakukan tahlilan dan scsudah tahlilan, pihak keluarga datang kekubur untuk menanam batu nisan. Diantara acara yang berkaitan dengan kematian, mattampung adalah upacara yang paling ramai dilaksanakan oleh keluarga. Upacara lainnya adalah peringatan hari keseratus dan acara haul (Bugis : mattemmu taun) pada waktu cukup satu tahun meninggalnya Almarhum.

Semua acara yang dilakukan untuk kern atian, imam desa atau imam dusun serta perangkat syara' mcmegang peranan, karena tujuannya adalah mendoakan almarhum-

\section{DI}

Pembauran antara kepercayaan lokal yang bersifat tradisional dengan ajaran Islam masih mcwarnai nilai-nilai yang dianut masyarakat Desa AllamungengpatuE Kabupaten Bone, yang pada umumnya menganut Agama Islam.

Aspek-aspek keagamaan dalam kehidupan sosial masyarakat, adalah menjalin hubungan dengan Allah Tuhan Pencipta dalam bentuk ibadah serta pelaksanaan upacara-upacara daur hidup, upacara tolak bala dan upacara keagamaan.

Dalam kehidupan sehari-hari, masyarakat masih terikat sistem norma dan adat yang masih diindahkan dan dipatuhi, dan dalam kehidupan beragama, mcrcka menggantungkan diri pada tokoh agama dan pemimpin mercka.

\section{Saran-Saran :}

Dalam masyarakat Desa Allamungeng PatuE Kab. Bone masih banyak ditemukan nilai-nilai dan tradisi yang menjadi kebudayaan yang dapat dikembangkan dalam rangka membentuk menusia yang utuh, sehingga kondisi kultural masyarakat akan lebih bennakna sebagai potensi pembangunan.

Upacara-upacara tradisional hendaknya diwarnai dengan ajaran Islam, untuk itu perlu adanya bimbingan dakwah yang mampu mengajak masyarakat untuk bertindak lebih rasional. Maka partisipasi aktif pemuka agama dibutuhkan untuk melestarikan kebudayaan disertai peningkatan kctakwaan tcrhadap Tuhan Yang Maha Esa. 


\section{KEPUSTAKAAN}

Andi Muh. Ali Bone Selayang Pandang, 1976 Brosur

Astrid S. Susanto, DR. Pengantar Sosiologi 1985 dan Perubahan Sosial, Bina Cipta, Jakarta.

Bachtiar Harsja W. Budaya dan Manusia 1985 Indonesia, Hanindita, Malang

B P L K Laporan Hasil Penelitian tentang 1985/1986 Masuknya Islam di Sulawesi Selatan, BPLK, Ujung Pandang.

Dep. P dan K Upacara Tradisional Daerah 1981 Sul.Sel.,DirjenKebudayaan, Ujungpandang.
Koentjaraningrat Manusia dan Kebudayaan 1970 di Indonesia, Djambatan, Jakarta.

Masyarakat Desa di Indone1985 sia, Universitas Indonesia, Jakarta.

Mattulada La Toa, Gajah Mada University, 1985 Jokyakarta.

Taufik Abdullah Agama dan Perubahan 1983 Sosial, Rajawali, Jakarta.

Widjaja, AN. Manusia Indonesia: Individu, 1986 Keluarga, dan Masyarakat, Akademi Pressindo, Jakarta. 